\title{
Formações nacionais de classe e raça'
}

\author{
Antonio Sérgio Alfredo Guimarães
}

Nas ciências sociais hoje, por pressão social, e por desdobramentos de vários campos teóricos - entre os quais, o feminismo, a teoria racial crítica e o descolonialismo -, não se pode pensar nas classes sociais sem levar em conta suas interseções com outras dimensões de agência e de determinação. No entanto, como bem comenta mais de uma autora, a ideia mesma de interseccionalidade, ao sugerir cruzamentos de categorias ou de relações preestabelecidas e fundadoras, pode descarrilhar dos processos históricos que são, afinal, o que pretendemos compreender (Bilge, 2013; Carastathis, 2014; Hancock, 2007; Lykke, 2010; Kergoat, 2011; Nash, 2008). O que há de mais fecundo na proposta feminista afinal é que os processos sociais reais, particularmente a formação de agentes e grupos sociais, ocorrem em ambiente de interações e determinações múltiplas e que os conceitos e categorias isoladamente nada mais são que resultado de nossos esforços analíticos. Do mesmo modo, progressos recentes nas teorias da etnicidade (Wimmer, 2008, 2013) e dos grupos sociais (Bourdieu, 1980, 2007) demonstram que tais processos ocorrem quase sempre em contextos comunitários mais abrangentes, como os Estados-nação. Ainda que para o desenvolvimento de uma teoria analítica mais abrangente seja necessário pensar transnacionalmente, as análises históricas precisam ser demarcadas por contextos nacionais.

1. Este artigo é uma versão ampliada e modificada de uma conferência proferida em agosto de 2015 no simpósio Os Negros e as Cidades Brasileiras (1890-1950), no Centro Universitário Maria Antonia (Ceuma-usp), São Paulo. Agradeço os comentários de Benno Alves, Edison Bertoncello, Flávia Rios, Matheus Gato e Válter Silvério. 
Estas reflexões sobre as interações entre processos de formação de classes sociais e raças, ou entre estruturas de classe e de raças, devem ser situadas, pois, no quadro mais geral do processo de formação nacional brasileiro. A possibilidade de sua generalização para outros contextos depende igualmente de que se explicitem novos marcos nacionais.

Todo meu esforço será concentrado em analisar como, no Brasil, os processos de racialização e de formação de classe são delimitados pelo pertencimento nacional, e como este último é constituído em relação a um certo ideário de classes sociais e de relação entre comunidades étnicas ou raciais. Opero, para tanto, de um modo original com os conceitos de racialização, desenvolvido por Banton (1977), de formação de classe (Przeworski, 1977) e de formação racial (Omi e Winnant, 1994).

\section{As classes}

O estatuto das classes sociais na teoria sociológica é controverso. Para limitar-me às correntes contemporâneas mais importantes para as quais este conceito é central, consideremos os marxistas e os weberianos. Para os primeiros, as classes fazem parte da teoria maior do materialismo histórico como agentes que impulsionam a história. As sociedades de classes, portanto, pré-datariam as sociedades burguesas e capitalistas. Os weberianos, ao contrário, restringem as classes temporalmente: elas seriam grupos sociais, ou seja, pressupõem-se indivíduos livres atuando em mercados. Nesse sentido preciso, mercados são mais que simples trocas materiais ocorrendo regularmente, pois para operar necessitam de um sistema de expectativas e disposições comportamentais que não apenas orientem, mas institucionalizem e regularizem as ações sociais. Ou seja, Weber não se preocupa com uma suposta realidade material que estruture a ação social a partir de fora, mas com o sistema de crenças, valores e atitudes que estruture a interação social a partir de dentro.

Se, em vez de nos aproximarmos do conceito teoricamente, nos voltarmos para a história das sociedades modernas, não elegeremos terreno menos ambíguo. A sociedade francesa, por exemplo, parece inexplicável, pelo menos até recentemente, sem entendermos a luta de classes ou as disputas entre categorias sociais, na realização de interesses materiais ou na defesa de privilégios ou status sociais. Ao contrário, na sociedade norte-americana, os indivíduos parecem ser realmente as unidades centrais da ação, congregando-se em grupos sociais diversos sempre em formação: religiosos, étnicos, raciais, de classe econômica, de sexo etc. A luta de classes, para os que querem enxergá-las, não agiria senão através de conflitos de outro tipo.

As considerações weberianas têm, diante da visão marxista, a virtude de chamar-nos a atenção para um fato que, muitas vezes, passa despercebido: as classes sociais, 
como conceito teórico aplicável apenas a sociedades de indivíduos e de mercados contêm em si uma normatividade implícita. Isto é, espera-se que os indivíduos e os grupos sociais que eles formam ajam de acordo com uma certa racionalidade, instrumental ou não, que dê inteligibilidade à vida social. Essa racionalidade busca ser, entretanto, universal e única: todas as demais possibilidades de agrupamentos devem-lhe ser subordinadas. Isso porque, baseando-se em mercados, herda-lhes o princípio de trocas de valores equivalentes e o pressuposto da igualdade e liberdade individuais. Todos os demais grupos sociais possíveis não reúnem tais virtudes normativas.

As classes sociais, portanto, aspiram a ser a expressão maior da liberdade e da igualdade individuais. Na versão marxista, tal igualdade é conspurcada pelo mais-valor, que fundamenta a teoria da exploração e o ideal revolucionário da sociedade sem classes. Nos Estados Unidos, por outro lado, os grupos raciais, étnicos e religiosos desenvolveram uma legitimidade correlata às classes: tais como nos mercados, a diferença entre credos, raças e cultura é o que garante a igualdade formal entre eles, desde que sejam manifestações da liberdade individual.

Fica claro, na trilha aberta por Weber, que a formação dos grupos sociais constitui processo histórico complexo (Bourdieu, 1987; Wimmer, 2013) que, no mundo contemporâneo, em cada sociedade nacional tem seus pressupostos. $\mathrm{O}$ primeiro destes, evidentemente, é que o Estado-nação em si mesmo, tal como constituído historicamente, tem, em momentos sincrônicos, a força institucional de se autorreproduzir e garantir a reprodução de outros grupos que contém. Por exemplo, os Estados Unidos da América garantem a reprodução dos grupos raciais, o que não acontece com o Estado-nacional francês. No Brasil, grupos raciais ou de cor são contabilizados pelo Estado desde o Império e recentemente passaram a ser sujeitos de direitos e objetos de políticas públicas.

As classes sociais podem, portanto, existir historicamente de modos distintos. Podem coexistir com outros grupos sociais, como etnias e raças, e nesse caso a distinção analítica feita por Marx ou Weber parece realizar-se completamente, pois as classes demarcam apenas posições sociais no mercado ou na estrutura econômica, enquanto outros princípios de demarcação grupal operam concomitantemente. Nesse caso, as classes se compõem não apenas de indivíduos, mas de diferentes grupos sociais (burguesia negra e branca; operariado negro e branco), denotando realidades interativas distintas. Ou, alternativamente, no outro extremo, podem subtrair outros grupos sociais, sobrepondo-se a eles, como em sociedades coloniais ou pós-coloniais em que as classes, grosso modo, coincidem com grupos raciais ou étnicos. Nesse caso, podem prevalecer os mercados e seus mecanismos, e as raças ou grupos étnicos parecem apenas como epifenômenos das relações de classe; ou, ao 
contrário, parecem não ter existência própria, visto que a exploração e a acumulação de riqueza se fazem diretamente entre grupos sociais em cooperação antagônica.

Do ponto de vista de sua formação social, as classes podem resumir-se à consciência daqueles que dominam e de sua pretensão de carisma (Elias, 1998), sendo as demais classes imputadas por eles como estigmas. Nesse caso, como acentuaram Elias e Scotson (1965), não há propriamente classes subalternas, pois todos aspiram às virtudes da classe dominante; outra possibilidade, aquela aventada por Marx, é que os explorados emirjam politicamente na luta de classes tomando consciência de sua exploração; ou ainda que, e essa é a possibilidade vislumbrada pelos teóricos durkheimianos (Grusky e Galescu, 2007), diversos grupos sociais se formem como categorias ou pequenas classes sociais em conflito cooperativo.

É dessas constatações que partimos para entender os processos interseccionais de classe e raça.

As raças

A raça, como identidade ou grupo social, também envolve muitas dificuldades teóricas para ser trabalhada. A começar pela distinção necessária entre, de um lado, a raça definida pelos outros, ou seja, raça-atribuida, e, de outro, raça assumida por $s i$, ou seja, raça reivindicada politicamente. São dois processos distintos, embora possam ocorrer simultaneamente. O primeiro, a que reservarei o termo racialização, é o que transforma um conjunto de indivíduos em um grupo racial subalterno, ou simplesmente em raça, a partir de características físicas hereditárias, reguladas pela reprodução biológica, tomadas arbitrariamente, mas justificadas por uma ideologia relativamente consistente, às vezes em bases consideradas científicas. Assim, por exemplo, os diferentes povos aprisionados na África e transportados como escravos para o Brasil colonial e imperial foram transformados, eles e seus descendentes, em negros ou raça negra, processo que se consolidou na Primeira República (Albuquerque, 2009; Weinstein, 2015). Esse processo, longe de ter sido definitivo e temporalmente delimitado, é social e está em constante operação, justamente porque indivíduos e grupos relutam em ser racializados. Ideologias individualistas, nacionalistas, regionalistas e, como vimos, a formação das classes sociais constituem recursos constantes na luta contra a racialização.

Da perspectiva individual, a racialização opera pela classificação espontânea de um indivíduo, um grupo, ou um agrupamento regional ou residencial em termos de raça: chama-se de negro ou negra uma pessoa, uma entidade, ou um bairro. Tal classificação fazemos pela nossa percepção social, nosso aparato simbólico, vividos como espontâneos, ou seja, sem reflexão, conforme nosso sistema classificatório 
disposicional, derivado do habitus, como teorizou Bourdieu (2007). Aqui vale ressaltar que, como Bourdieu insistiu, o habitus não explica apenas a reprodução, mas também a mudança. Ou seja, nada garante que indivíduos nascidos em uma certa posição social incorporem integralmente o sistema de disposições, valores e atitudes de sua classe. Da perspectiva coletiva, a racialização condensa-se em instituições, e esse sistema classificatório torna-se reflexivo, cristalizando-se em saberes e ideologias, organizados e sistematizados, geralmente em relação a outros saberes. Essa é também a perspectiva de quem classifica. Por certo, no plano individual, quando se racializa um outro está-se ao mesmo tempo racializando-se a si mesmo, visto que classificar alguém como negro significa quase imediatamente classificar-se a si como branco, pardo, amarelo, ou outra designação. Historicamente, não existe raça negra sem raça branca, ou africanos sem europeus. Mas essa lógica pode ser enganosa: quem tem o poder de classificar os outros busca para si a transcendência, a universalidade, um espaço simbólico e espiritual que ultrapasse o corpo, os limites biológicos ou o gueto - espaços de emparedamento, isolamento e segregação.

Quero distinguir racialização de formação racial. Processo que transcorre da perspectiva de quem é racialmente classificado, emparedado, como figurou Cruz e Souza, num corpo, num gueto, numa cultura étnica particular. Formação racial é um conceito que prefiro aplicar para o processo de construção de uma contraidentidade racial positiva, uma prática política contra-hegemônica de formação de coletivos raciais, não apenas de indivíduos. Um processo que rompe as paredes, transcende o corpo, transpõe o gueto, ultrapassa-o rumo à cidade. Como é basilar em nossa disciplina, fenômenos como esse não se constituem por simples agregação de vontades individuais (Durkheim, 1894), mas têm uma realidade própria que se cristaliza em representações e ações coletivas, contingenciadas por estruturas sociais e situações históricas particulares. Este é um processo que envolve agentes, tanto individuais quanto coletivos, e instituições. Ou seja, lideranças, movimentos sociais e aparelhos estatais ou não estatais, assim como os mercados, estão presentes na formação racial.

Volto a ressaltar que o uso que faço desses termos difere do modo como são correntemente utilizados na sociologia, introduzidos pelos autores que os cunharam, Banton (1967) e Omi e Winnat (1994). Ambos usam racialização, no caso de Banton, e formação racial, no caso de Omi e Winnant, indistintamente para se referirem tanto à atribuição, quanto à assunção racial (Silvério, 2013). Creio que, fazendo a distinção dos conceitos para aplicá-los a processos distintos, ganhamos em clareza e precisão.

A contraposição à racialização pode ser, como já disse, e de fato foi assim no Brasil, a formação nacional ou mesmo a regional. A tentativa de definir a nação a partir da mistura de três raças, em que elas sobrevivem apenas como filtros para a 
definição de cores próprias à mestiçagem, foi uma estratégia que se contrapôs à pura $\mathrm{e}$ simples racialização de coletivos, que levaria a polaridades. No Brasil, essa estratégia tem sido utilizada desde pelo menos meados do século XIX (Martius e Rodrigues, 1956). Nesse caso, a racialização não logrou formar coletivos racializados com atuação política forte. Sendo todos brasileiros, sabíamos ter cores diferentes oriundas da miscigenação. Todos, dos mais negros aos mais brancos, dos mais escuros aos mais claros, teríamos emergido de uma mistura racial. Essa crença, aliás, tornara-se consagrada pela ciência biológica no final do século XIX, já que não existiriam raças humanas puras, mas apenas populações em graus diversos de clausura. Em seus efeitos individuais, a cor era um tropo para raça, mas coletivamente dificultava a formação racial. No entanto, a nossa formação nacional foi racializada, e durante muito tempo tivemos, se é que não continuamos tendo, ainda, dificuldades de nos livrarmos do sentimento colonial de inferioridade nacional, tão bem alcunhado por Nelson Rodrigues (1958) de complexo de vira-latas.

\section{A ciência e a racialização}

Mas voltemos no tempo para lembrar como se conformou o mundo teórico, ou seja, o consenso de percepção, no que respeita às raças. Esse consenso formou-se no pós-guerra e, embora já não exista de maneira íntegra, nos ajudará a compreender como se está dando a sua ruptura.

O consenso formou-se em relação ao racismo que levou ao holocausto: estava claro para todos que as ciências biológicas não poderiam explicar a violência exterminadora do fascismo em vários Estados nacionais, muito menos a banalização do mal, como o chamou Hannah Arendt (1994). Tornou-se óbvio que a violência e o extermínio não tinham como base o suposto e mítico ódio atávico entre as raças, pelo simples fato de que não existem raças humanas, ao menos no sentido em que as definimos no mundo social e simbólico.

A primeira solução proposta para erradicar o racismo pelos cientistas sociais reunidos pela Unesco em 1949, em Paris, foi banir o próprio termo raça. O racismo derivaria da crença em raças humanas, que não teria base científica suficientemente sólida para sustentá-la. As ciências, ao se utilizarem do conceito de raça, serviriam apenas para dar legitimidade e força simbólica às relações de poder que subordinavam, oprimiam e exploravam coletivos sociais em todos os continentes. Em nossos termos: as ciências, ao usarem o termo raça, perpetuariam a ideologia que o sustentava, ajudando assim a institucionalizar a racialização. $\mathrm{O}$ desdobramento mais importante da Primeira Declaração sobre Raça da Unesco foi, entretanto, universalizar a compreensão de que o racismo começa quando se pretende explicar 
a cultura e a sociedade pela natureza física ou biológica. $\mathrm{O}$ racismo seria a redução da sociedade à natureza, a substituição da compreensão das culturas humanas pela explicação naturalista.

As resoluções de 1948, entretanto, ficaram como meias verdades. Como deixou claro a segunda reunião de cientistas, agora majoritariamente das ciências naturais, convocada pela Unesco em 1951, justamente para rever a primeira declaração, a raça era um conceito do qual as ciências naturais relutavam em abrir mão. E, acrescento, que se revelaria também imprescindível para a luta política contra o racismo nos Estados Unidos e outras partes do mundo, como veremos adiante. Manteve-se, contudo, o consenso de que as ciências naturais não poderiam explicar relações sociais.

Ainda assim, apesar desse consenso, uma análise mais cuidadosa mostra que havia frestas pelas quais o consenso poderia ser relativizado, como de fato está sendo até os dias de hoje. Essas frestas estão, elas mesmas, nas diferentes correntes teóricas das ciências sociais. Exemplifico-as com três das mais importantes nos dias que correm: 1) as formações sociais explicadas pelas relações de produção e de exploração; 2) a cultura e a sociedade entendidas como sistemas simbólicos; e 3 ) as sociedades humanas analisadas como relações sociais de poder.

Para sociólogos que se filiam às duas primeiras, a colaboração entre as ciências naturais e sociais tornou-se, com o passar do tempo, quase inexistente. Dois mundos que continuam a se desenvolver quase que sem interação ou interlocução direta. Mas, para cientistas da última corrente, na tradição de Max Weber (2006) e de Norbert Elias (1987), não há afastamento definitivo entre o mundo biológico e o social. A colaboração entre ciências naturais e sociais foi apenas adiada para quando as primeiras pudessem realmente ajudar no esclarecimento de fenômenos sociais sem reduzi-los a fenômenos físicos ou naturais. Afinal, haveria um substrato biológico no comportamento humano que não teria por que ser banido de antemão por decisão política dos cientistas.

Em épocas de grande tensão racial como a que estamos vivendo, há sempre a tentação de se acreditar que, finalmente, as ciências naturais podem nos ajudar a esclarecer fenômenos sociais, tanto quanto ajudam desde há muito a curar os males de nossos corpos.

Esse perigo foi denunciado por Troy Duster (2003) em livro já famoso. Denúncia reiterada por Duster (2006) em sua fala presidencial à Associação Americana de Sociologia (ASA), em que analisa as consequências reducionistas da introdução de variáveis naturais, como a coleta de sangue para teste de DNA em pesquisas sociológicas que pretendem medir com precisão a raça dos entrevistados. Duster e Bourdieu, no prefácio à segunda edição de Backdoor to eugenics, rebatem a crítica estúpida ao construtivismo social feita recentemente por alguns sociólogos norte-americanos. 
Aqui na América Latina, Peter Wade, Ricardo Santos, Carlos López-Beltrán e outros (2015) acusam a fragilidade metodológica e teórica dos estudos sobre a diversidade fenotípica das populações humanas, principalmente sua base amostral e seus pressupostos de representatividade de populações ancestrais.

\section{Cor e grupos de cor}

Mas o fato é que até mesmo respeitáveis estudiosos das relações raciais, como Michael Banton (2012), que continuam a negar a existência de raças humanas, recorrem à ciência genômica para introduzir na sociologia a categoria cor de pele, tratando-a como realidade natural, determinável pela biologia molecular. Eles confundem a classificação por cor de pele, que é considerada politicamente correta em todo o mundo ocidental, cada vez mais, com a classificação de cor que utilizamos no Brasil. O uso de paletas de cor, como a utilizada por Edward Telles (2014) em seu excelente projeto sobre as classificações raciais nas Américas, se multiplica, mas nem sempre são manipuladas com os devidos cuidados metodológicos antirreducionistas e antiessencialistas.

O sistema de classificação racial por cor, tal como o conhecemos no Brasil, foi estudado pela geração de cientistas sociais dos anos de 1950 e 1960. No sistema brasileiro clássico, explicitado por Wagley (1952), Azevedo (1956), Harris e Kotak (1963) e outros, cor não é redutível à “cor da pele”, à simples tonalidade. Cor é apenas um, o principal certamente, dos traços físicos - junto com o cabelo, nariz e lábios - que, juntamente com traços culturais - "boas maneiras", domínio da cultura europeia -, formavam um gradiente evolutivo de embranquecimento: preto, pardo, branco. No grupo branco nunca se hesitaria em classificar alguém de pele escura, mas traços "finos" (europeus) e boa educação. Entre os pardos, estavam certamente aqueles de traços físicos "negroides", mas claros e bem-educados.

É esse sistema de classificação racial por cor que vem sendo paulatinamente modificado no Brasil, à medida que o ideal de embranquecimento vem perdendo força (Guimarães, 2012b).

De um lado, pela ação de sua organização política, os negros rejeitam frontalmente o embranquecimento e tentam impor uma noção histórica, política ou étnica de raça. Quando se remetem à história, a noção de raça reúne pessoas que vivenciaram uma experiência comum de opressão; quando se remetem à política, o sentido de raça cria uma associação em torno de reivindicações; quando se remetem à etnia, o uso da raça quer criar um sentimento de comunidade a partir da cultura. Em todos os casos, os gradientes de cor seriam contraprodutivos, se não fossem reagrupados para tornar pretos e pardos uma única categoria discreta (descontínua), que bem poderia ser batizada de afrodescendentes ou negros. 
De outro lado, a classificação por cor vem também sendo enfraquecida pela reintrodução do termo raça no discurso público e pela sua introdução nas estatísticas oficiais. O IBGE (2008) conduziu uma pesquisa amostral para entender que dimensões eram mobilizadas pelos recenseados quando instados a se classificarem por cor ou raça. O resultado aponta, a meu ver, um aumento da importância da categoria cor da pele, a permanência de categorias da raciologia do século XIX, ou seja, os traços físicos, mas aponta também para o surgimento de novas dimensões classificatórias, sugeridas pela categoria raça, usada pelo ativismo político negro.

Minha sugestão é que o nosso sistema tradicional de classificação está sendo modificado pela perda de sentido do ideal de embranquecimento. Ou seja, estaríamos assistindo não apenas a uma reclassificação de indivíduos por categorias que permanecem as mesmas, mas à mudança de significado cultural e simbólico dessas mesmas categorias.

Formação racial

Aqui cabe a pergunta: Por que os negros brasileiros não continuaram a resistir à racialização, por que optaram recentemente por assumir a raça, ou seja, a se formarem enquanto raça ${ }^{2}$

Começo por recordar que este não é um fenômeno sui generis, antes do Brasil já tinha ocorrido nos Estados Unidos. A novidade é que se considerava a formação racial norte-americana excepcional, em vista das formações raciais latino-americanas, todas elas muito embebidas de ideários nacionais. O que parecia decisivo nos Estados Unidos era que a discriminação e a segregação raciais muito mais fortes impediam uma integração nacional mais completa, ao contrário de países como Brasil, Cuba ou Colômbia. Será a raça para os negros nas formações sociais ocidentais uma herança inescapável? Aceitando, a princípio, tal tese, eu a desdobrarei construindo, em poucas palavras, uma moldura histórico-conceitual que melhor a enquadre.

Diferentemente de outros povos formados em diáspora ou oriundos de imigração, os milhões de africanos trazidos escravizados para as Américas e os seus descendentes não se constituíram como etnias em seus novos hábitats, mas sim como raça. O mesmo pode ser dito para aqueles que, séculos depois, imigraram livremente das jovens nações africanas para o Ocidente em busca de trabalho. Os africanos de ontem e de hoje foram e são em geral definidos negativa ou positivamente por características fisionômicas e fenotípicas, e não pela cultura ou nacionalidade de origem. Nas Américas, mesmo no Brasil, onde traços das culturas que trouxeram da África 
marcaram profundamente a cultura popular e fundiram-se à cultura nacional e às identidades regionais, apenas a mobilização pela raça lhes permitiu avançar, como coletivo, reivindicações de direitos civis. Para os negros, como muito bem salientou Du Bois (1903), a dupla consciência de raça e de nacionalidade foi e continua sendo condição para integração social e política.

Em outros termos: a formação de classes não foi capaz de anular os efeitos materiais da racialização, isto é, seus efeitos de classe, seja porque as classes ganharam marcadores fenotípicos mais duradouros (por exemplo, ser negro tornou-se sinônimo de pobreza), seja porque a discriminação racial impediu que etnias e raças desaparecessem, engolfadas por forte solidariedade de classes.

Este único fato marca a grande diferença entre os negros no Ocidente e outros povos formados em diáspora, que se cristalizaram, ao contrário, como minoria étnica ou religiosa, ao lado de outras minorias nos Estados-nações europeus, surgidas na Idade Moderna. Semelhante aos negros parece ser hoje em dia o que ocorre com os árabes e muçulmanos na Europa. Os judeus, ao contrário, por muito tempo, desde a formação dos Estados-nação laicos, resistiram com sucesso, ainda que de forma muitas vezes trágica, ao processo de racialização que lhes quiseram impor: a religião e a cultura, desenvolvidas à sua margem, serviram-lhes de cimento identitário. Nesse caso, a duplicidade de consciência não medrava, pois a pluralidade de suas identidades sociais se assemelhava àquela das variações admitidas pelo Estado-nação republicano e democrático: eram portadores de especificidades religiosas e culturais, tal como outros coletivos são portadores de subculturas regionais, étnicas ou religiosas. No Brasil, continuaram sendo brasileiros comuns tal como os protestantes, os evangélicos ou os espíritas, ao lado dos católicos.

Como os negros, também os descendentes dos japoneses que imigraram para as Américas continuam, de certo modo, a se diferenciar fenotipicamente dos demais americanos e brasileiros, a depender de seu grau de miscigenação. No entanto, eles também resistiram com relativo sucesso à racialização, atendo-se à referência nacional de sua origem, muito mais forte que a designação de raça amarela que se lhes quis impor a imaginação racista. Assim, em vez de amarelos, foram e continuam sendo japoneses, chineses, coreanos ou indianos, em qualquer país da Europa ou da América. As variações, ainda que dignas de nota, não vêm ao caso. Por exemplo: são “japoneses” ou “japa”, no Brasil, e nipo-americanos, nos Estados Unidos.

É bem verdade que a cultura e a religião, no caso dos negros, serviram de núcleo a partir do qual a identidade racial pôde desenvolver-se e solidificar-se. Costumes alimentares e de lazer - como o samba e a feijoada crioulizada por cozinheiras negras - ou religiosos - como a devoção a certos santos, o candomblé, xangô ou batuque - serviram de esteio para agrupar de maneira mais duradoura pessoas so- 
cialmente muito diversas, mas que tinham na "cor", ou seja, na raça atribuída, uma especificidade negativamente valorizada pela formação nacional; e nos preconceitos de cor, práticas atualizadoras da diferença. Não se trata, portanto, de negar o papel da especificidade cultural na formação racial dos negros. Trata-se, isto sim, de salientar o fato de que a principal referência identitária de outros povos diaspóricos gravitou sempre em torno de símbolos culturais, oferecidos pela nação ou religião de origem, enquanto, no caso dos negros, tal referência nunca foi tão forte quanto à raça, o principal marcador diacrítico da identidade coletiva.

Como já salientei, houve tentativas no sentido de que a nacionalidade e não a raça marcasse prioritariamente a identidade negra nas Américas. Identidades nacionais consolidadas entre os anos de 1920 e 1950, no Caribe e na América do Sul, são provas cabais dessas tentativas. As nações caribenhas e latino-americanas, em sua maioria, forjaram para si uma nova identidade metarracial, desvencilhando-se da mestiçagem como estigma de inferioridade racial e, mais que isso, transformando tal estigma em carisma, ou seja, em marcador diacrítico positivo. Quando isso aconteceu, os negros foram instados a afastar-se cultural e sentimentalmente do continente de origem para tornarem-se cem por cento nacionais dos novos Estados americanos. Apenas os países americanos podiam ser suas nações. Guerreiro Ramos (1957) notou com acuidade, assim como outros de sua geração, que eram eles, os negros, os verdadeiros brasileiros, ou seja, aqueles que não poderiam reivindicar nenhuma outra nacionalidade ou cultura. Isto é, os negros não poderiam ter outra identidade nacional que a de brasileiros - "negro é o povo brasileiro", dizia Guerreiro. No entanto, a força dos estereótipos raciais que os identificava como negros, como se a cor fosse algo intransponível, atribuída pela definição-pelos-outros, sempre prevaleceu sobre a definição nacional feita-por-si.

O processo de mestiçagem foi, até certo ponto, bem-sucedido, se tomarmos como parâmetro o fato de que boa parte dos mestiços se desvencilhou de referências culturais africanas ou indígenas, chegando mesmo os mestiços claros a assimilarem-se completamente ao mundo cultural e sentimental latino-americano de expressão europeia. Digo "de expressão europeia" porque esses mundos mestiços latino-americanos conservaram os valores europeus como referentes últimos pelos quais se identificam. O que restou de "cultura africana" ou indígena foi gradualmente absorvido pelas culturas nacionais. Mas tal sucesso teve seus limites, exatamente, na persistência do sentimento de inferioridade mestiço, no preconceito de cor e na ampliação das desigualdades sociais entre negros e brancos daí decorrentes. De modo que a raça continuou sendo um referencial importante, fosse para alimentar o complexo de inferioridade, o preconceito e a discriminação, fosse para a construção de identidades raciais de combate e de afirmação social e cultural dos que não puderam 
ser plenamente absorvidos pelo projeto de mestiçagem ou contra ele se insurgiram. Foram exemplos, no Brasil, desses movimentos raciais positivos de contestação a Frente Negra Brasileira (anos de 1930), o Teatro Experimental do Negro (anos de 1950), o Movimento Negro Unificado (anos de 1980), entre tantos outros de menor repercussão sobre a vida política nacional.

Raça e cor, e não nações, foram referências para tais movimentos. As antigas nações africanas da época do tráfico negreiro foram abandonadas e persistiram apenas como denominações coloniais ou como instrumentos de genealogia cultural. Nunca houve, portanto, uma referência nacional moderna africana que servisse de contraponto à estereotipização racial.

O que acabo de salientar é muito importante para compreendermos o dilema em que vivem os negros quando instados a procederem segundo normas universalistas e republicanas de cidadania, renegando qualquer política pública que os beneficie enquanto raça. Ora, a única mobilização possível que unifica os negros - ou seja, os que são tratados como negros - é através da noção de raça. Por isso mesmo a noção é retrabalhada teoricamente pelos movimentos sociais para lhe retirar qualquer ranço racista (que pregue a superioridade racial). De raça definida pelos outros, negativamente, a partir da generalização pars pro toto de deficiências morais, biológicas ou sociais, para raça definida por si, generalizando carismas com marcadores culturais e históricos.

A meta de negação de qualquer especificidade racial e cultural, definindo-se como cem por cento brasileiros, mostrou-se idealista e impossível de ser cumprida, até mesmo porque os brasileiros, em sua maioria, não querem ser apenas brasileiros. Somos brasileiros, mas não deixamos de ser baianos, paulistas, homens e mulheres, ricos e pobres, negros e brancos, católicos, evangélicos etc. (identidades regionais, sexuais, de classe, raciais e religiosas). Se assim é, como mobilizar-se politicamente contra a discriminação racial sem mobilizar-se em raça? De fato, como já disse, alternativas existem para outros povos discriminados: podem-se mobilizar como judeus, como japoneses, como sírio-libaneses, formando clubes, associações etc.; o mesmo se aplica às mulheres, aos homossexuais, aos deficientes físicos, aos indígenas e a outros.

Alguns intelectuais abraçaram o socialismo para se manterem coerentes com o universalismo e o hipernacionalismo que se pediam aos negros. Para os socialistas, os negros eram pobres, explorados e sem usufruírem plenamente seus direitos, tal como todos os trabalhadores sob o capitalismo imperialista. Essa formação pela via da luta de classes e pela arregimentação socialista prevaleceu por bastante tempo no século XX nos meios negros brasileiros e contou com a simpatia e a solidariedade internacionais, não apenas dos comunistas europeus, mas dos comunistas negros norte-americanos e latinos. 
Difícil explicar, tal a força dessas ideias que germinaram nos meios negros brasileiros, por que essa vocação universalista cedeu lugar à mobilização mais nitidamente racial e mesmo étnico-racial dos últimos anos. Há fatores externos e internos a considerar.

Começo pelos últimos. Embora não possa desenvolver aqui a riqueza e a complexidade desse processo, proponho uma interpretação possível, para futuras pesquisas. Parto da hipótese de que a formação nacional brasileira, como povo miscigenado, não logrou contrapor-se à racialização de modo efetivo, visto que deixou vicejar entre nós certo sentimento de inferioridade de povo mestiço (Rodrigues, 1958). Assim, deixou-se campear entre nós um sistema de classificação racial que restringiu a raça negra, sem transformar realmente o Brasil em um país branco ou pós-racialista. Por outro lado, faltou-nos até os anos de 1970 a formação de uma classe trabalhadora com ideologias, valores e interesses bem definidos. Vale lembrar que sociólogos como Alain Tourraine (1961) se lamentavam da ausência de consciência de classe de nossos operários industriais de origem rural, absorvidos em sindicatos clientelísticos. $\mathrm{Ou}$ seja, prevaleceu no pós-guerra uma homologia de narrativas negativas - de nação, de classes sociais e de raças. As formações dos anos de 1970 e 1980 contrapuseram-se, portanto, ao imaginário estigmatizador de nação de mestiços sem raça e sem classe; o país do futuro impondo-se ao "país vira-latas".

Mas há que se lembrar de que fenômenos análogos de formação de grupos sociais trespassaram todo o mundo ocidental a partir dos anos de 1970, dando espaço à formação do que os sociólogos vieram a batizar como "novos movimentos sociais". O movimento feminista, o movimento gay, o movimento de bairros, até mesmo o novo sindicalismo brasileiro, ainda que inspirados pela herança universalista marxista, pouco a pouco, foram desenvolvendo identidades e ideais mais delimitados em torno do gênero, da preferência sexual, dos problemas locais e propriamente sindicais.

No caso dos negros, vale repetir que a raça (às vezes a cor) foi sempre um marcador primordial para o destino pessoal de qualquer negro no Brasil. Assim, a ascensão social, o aburguesamento, o sucesso pessoal, a celebridade, o cultivo pessoal da alta cultura europeia como forma de expressão, nada evitou - nunca - que um negro fosse um negro.

Que elementos facilitaram a formação racial? Em vez de responder em termos teóricos, o que nos levaria a modelos abstratos, tomemos o exemplo brasileiro. Joaquim Nabuco, em sua luta abolicionista, considerava ter o "mandato da raça negra", o que supunha a inexistência ou a menoridade política desta. Desde a Primeira República, contudo, já encontramos políticos que se definiam como negros e porta-vozes do povo negro. A crença em uma nação mestiça, portanto, que serviu de contraponto à racialização, não anulou, mas, ao contrário, ensejou o multirracialismo. No entanto, 
foi em momentos de crises da nacionalidade brasileira mestiça, aguçadas quase sempre por crises econômicas e políticas, que projetos de formação racial vingaram: os anos de 1930, a redemocratização dos anos de 1940 e 1970. Vivenciamos desde o início dessa nossa Terceira República tal processo de formação, avivado em lutas políticas vitoriosas pelo reconhecimento da especificidade cultural dos afrodescendentes e pela implantação de ações afirmativas em diversos âmbitos.

Nos três períodos republicanos temos experimentado a constante oscilação no sentido de que formas de dominação por mecanismos de mercado prevaleçam sobre formas diretas, o que implica a lenta transição de uma ordem hierarquizada pelo status ou estatuto social dos indivíduos para uma ordem regulada pelo mercado de bens e serviços, ou seja, pela hierarquia das classes sociais. A transformação principal foi aquela que mais nos interessa aqui: a passagem do trabalho escravo ou assujeitado para o trabalho livre. Isso afetou diretamente a regulação da sexualidade, os papéis de gênero, a divisão sexual do trabalho, fatos que ocorreram entre as raças e grupos de cor, e entre as classes sociais. Classe, nesse contexto, foi muito mais que situação de mercado ou relação com os meios de produção - tornou-se uma comunidade formada a partir de atitudes, valores e formas de representação de si.

Racialização, formação racial e espaço urbano

Voltemos à racialização, pensando agora em mecanismos atuantes nos espaços urbanos de ideologias dominantes. A segregação racial, que transforma quarteirões e bairros inteiros em territórios brancos ou negros, é sem dúvida um deles. O gueto é o equivalente ao corpo negro. Uma rápida visita à Cidade do Cabo, anos atrás, fez-me perceber que havia ali bairros burgueses que eram locais de moradia para brancos, e de trabalho, para negros. Em outros, todavia, a população tanto de trabalhadores, quanto de moradores, tinha a mesma cor ou raça (Coloured e African) e sua diferença se reduzia à classe social. Há cidades brasileiras em que ainda é norma das classes burguesas terem muitos serviçais domésticos negros, alguns dos quais ainda dormem nas residências onde trabalham. Podem-se assim encontrar situações muito diversas em que a segregação se dará, seja nas ruas das áreas residenciais, seja no interior das casas. No primeiro caso, diferenças de raça, cor, classe e sexo vão estar visíveis entre quem reside e quem trabalha ali; no segundo caso, a arquitetura de interiores nos dirá os espaços de sociabilidade de residentes e de serviçais. Creches, escolas, hospitais, serviços públicos em geral não estarão voltados para atender à população trabalhadora desses bairros, apenas o transporte público. Quanto maior a distância social entre residentes e trabalhadores, maior será a segregação na mobilidade urbana: ônibus para trabalhadores, automóveis para residentes. 
A tendência no Brasil, nas áreas residenciais de classe média, tem sido a diminuição do número de empregados residentes nos domicílios que os empregam; uma lenta mudança na arquitetura dos interiores, com o desaparecimento dos elevadores exclusivos, dos "quartos de empregada" e, consequentemente, a utilização menos exclusiva dos transportes públicos pelas classes trabalhadoras. A diminuição do trabalho doméstico remunerado, entretanto, fortalece a segregação residencial e dos serviços de saúde e de educação. Os bairros tornam-se menos "misturados"; e as distinções de classe, cor, raça e gênero, mais nítidas. Isso em termos gerais, pois tudo varia de acordo com a história de cada cidade e de cada bairro, sua geografia e sua história política.

Fundamental nesse processo de segregação racial em sociedades de classes têm sido o mercado imobiliário e as políticas públicas. Um exemplo limite é a desvalorização de imóveis e de áreas urbanas inteiras pela presença de raças indesejadas e a estratégia defensiva dos proprietários de evitar tal desvalorização pela discriminação na hora de alugar ou vender. Mas tal segregação pode ocorrer sem discriminação direta. É o caso de grandes empreendimentos imobiliários que desalojam antigos residentes, sobrevalorizando terrenos e aluguéis, e ensejam a quebra de antigos estabelecimentos comerciais e sua substituição por novos; ou a ausência de equipamentos como creches públicas em bairros de alta renda, onde as usuárias seriam mulheres no emprego doméstico. A simetria entre raça e classe, ou seja, a homogeneidade racial de segmentos inteiros de classes sociais, pode ensejar a segregação racial por simples mecanismos de mercado. No caso das políticas públicas, a ausência de transporte coletivo em certos bairros condominiais incentiva a residência apenas daqueles que podem financiar a sua própria mobilidade urbana. Do mesmo modo, pode-se buscar entender a lógica social e racial da malha de linhas de transporte público, que unem áreas de trabalho, lazer e consumo.

A formação racial tem também uma lógica espacial. Para começar, a concentração em bairros ou quarteiróes de moradores socialmente homogêneos ocorre pela concorrência de processos como a imigração e os mecanismos de mercado, como preços relativos de transporte, de aluguel e de terrenos, pela oferta de serviços públicos etc. Em bairros e quarteirões de constituição socialmente homogênea, a raça ou a cultura de origem pode ser um fator a fortalecer o sentimento comunitário de vizinhança, contrariando os fatores de diferenciação social sempre presentes. Bares, espaços de lazer, sindicatos, igrejas e clubes que reúnam grupos de imigrantes, racializados ou etnicizados, como negros, baianos, nordestinos etc., podem com mais facilidade servir de veículos à produção cultural e simbólica de representação coletiva alternativa aos da sociedade envolvente.

Para finalizar, concentro-me nas consequências do processo atual de formação racial no Brasil. 
Ressaltei que um dos seus pontos cruciais e mais radicais tem sido a desorganização do sistema classificatório de cor, que secularmente se contrapôs à racialização, para, ao contrário, reafirmar a categorização racial, pela qual pretos e pardos se afirmam como raça negra. Os efeitos dessa política fazem-se mais fortes em escolas e universidades, locais onde tal jogo de reclassificação pode ser vivenciado como experiência positiva através das cotas e dos estudos afro-brasileiros e diaspóricos. A formação racial abandona, assim, o terreno das periferias, das margens e das comunidades segregadas, para brigar no terreno onde se forjam as identidades nacionais unificadoras, espaço por excelência de reprodução de ideologias dominantes. Como já vimos, dimensões de pertencimento cultural e étnico, de ancestralidade e mesmo de supervalorização da cor da pele em detrimento de outros caracteres físicos começam a pesar mais na definição racial que as antigas dimensões de pertencimento de classe e de aculturação europeia. Ou seja, tal política de formação racial começa a afetar o todo nacional e não apenas a periferia de seu sistema. Acrescente-se que pari passu, cada vez mais, há uma política dos subalternos, reconhecida pelos governos municipais, de ocupação de áreas ou mesmo de edificações em terrenos centrais ou valorizados, a contrapelo da lógica de mercado. Ou seja, em ambos os casos, a lógica da dominação de classe é subvertida e sua reprodução por mecanismos de mercado é contrariada, seja pela formação racial, seja pelo contraurbanismo.

Na verdade, adotei neste artigo um conjunto limitado de perspectivas, que podem ser alargadas: cidades e corpos, o eu e o outro, a raça e a cor, o biológico e o simbólico, o individual e o coletivo. As cidades são espaços de transposição de barreiras culturais, mas podem ser vivenciadas também como guetos, assim como o corpo pode ser vivenciado como hedonismo ou sofrimento, domínio ou emparedamento do espírito e da mente.

Continuo a pensar, como Weber (2006) ensina, que a genética das raças ainda hoje não nos ajuda a compreender a ação social, embora possa contribuir muitíssimo para acelerar os processos de racialização mundo afora. A formação racial de que tratamos é um processo de afirmação de cidadania, de pleno uso das potencialidades das cidades, que se faz contra a racialização para afirmar justamente o caráter universal da espécie humana.

\section{Post-scriptum: esclarecimentos}

Apresentado, primeiro, como palestra, este texto suscitou algumas dúvidas que procurei esclarecer. A primeira tem a ver com a formação racial dos brancos, chamada branquitude. Seria ela uma decorrência da racialização do Outro, no caso os negros? Ou seja, será que o branco se forma enquanto raça apenas para oprimir e subordinar? 
No mais das vezes, eu diria que sim. Mas é preciso lembrar que os povos colonizadores retiram seu poder hegemônico não apenas da força militar e da escravização, ou seja, do sistema de exploração econômica, mas sua hegemonia se consolida ao oferecer soluções culturais e científicas aos males da espécie humana. Nesse sentido, sua dominação legitima-se rompendo com os limites estreitos de outras pertenças. Os colonizadores procuraram representar o Homem - a espécie e o sexo masculino - com potencial de englobar a todos. Sua ciência salva vidas e cura corpos, sua religião salva almas, sua cultura promete eternidade ao espírito e às suas construções, sua dominação civiliza. Seu projeto não é de ser um simples reverso de outra raça. Isso nos ensina que a formação racial negra tem também o desafio de romper a cápsula em que foi criada, e, em vez de ser apenas uma maneira de encontrar satisfação e orgulho no seu emparedamento, rompê-lo em busca da universalidade e da humanidade que lhe quiseram retirar. Ser superior, no caso dos racializados, deve, inclusive, ir mais além do que aspirar à universalidade do Homem, mas atingir o ser humano, para além dos sexos e de todas as demais hierarquias. As ciências sociais, as artes e humanidades, a filosofia, todas oferecem instrumentos para essa formação universalista. Racialização, portanto, é um processo de opressão, de balcanização e de desumanização, enquanto a formação racial, quando deixa de ser simples reverso da racialização, aspira ao universalismo.

Mas, se assim é, qual a relação entre os pares racialização/formação racial, que agora avanço teoricamente, e o binômico racismo/antirracismo de que me servi durante tanto tempo?

De fato, nos anos de 1990, enfatizei muito essas duas constelações discursivas, talvez refletindo em demasia a minha formação marxista analítica e "estruturalista". À medida que a sociologia histórica começou a pesar mais sobre minha reflexão, passei a ressaltar processos sociais e a agência coletiva e individual na compreensão da história. Dito isso, devo acrescentar que a racialização é sempre um discurso racista, enquanto a formação racial é um antirracismo. A formação racial, na tradição fanoniana, é uma luta antirracista e anticolonial - de liberação de mentes e corpos emparedados, de emancipação de culturas coloniais e colonizadas. Essa luta não deve criar um racismo às avessas, mas uma nova cultura ou transcultura, para usar Fernando Ortiz (1940), descolonial, autêntica, que busca firmar um novo humanismo. Essa é a utopia que deve mover a formação racial.

Mas há complicadores no mundo real. A racialização dos outros pode ensejar uma formação racial de si como raça superior, em uma espécie de multirracialismo hierárquico; ou pode proceder simplesmente à construção de raças sub-humanas ou apenas potencialmente humanas; o racializador guardando para si a integralidade das virtudes da espécie. A formação racial, do mesmo modo, pode apenas replicar a racialização existente, constituindo-se num racismo contrarracista. 
Alguém pode objetar que a minha compreensão da racialização fica muito próxima de estender ao Estado o papel de favorecimento desse processo ao adotar categorias raciais, como ocorreu com o sistema de ingresso nas universidades federais brasileiras através de cotas.

Ora, o Estado é, no final de contas, a cristalização das correlações de força que estão em luta no mundo social. Hoje, todas as categorias raciais usadas pelo Estado brasileiro para classificar pessoas em grupos foram, de certo modo, vitórias do movimento e da formação racial negras. Nesse sentido, ele é um aliado na luta contra a racialização. Isso não significa que essa correlação de forças seja definitiva e vá perdurar. A racialização não é um processo pretérito, mas permanente. $\mathrm{O}$ mesmo vale para a formação racial.

A biologização das ciências sociais, a naturalização da raça negra, através de toda a ideologia que toma emprestada a linguagem da teoria molecular para criar uma nova mística racial, essa sim é um golpe ao processo de formação racial negra. Ela a reverte ao nível do avesso da racialização. Esse é um perigo muito mais premente que o Estado.

O fascínio pelas origens e pela ancestralidade, a busca de testes de DNA para se descobrir sua terra de origem, tudo isso é prosaicamente humano. Temos necessidade disso. O problema é que devemos tratar esses nossos anseios pelo que eles realmente são: místicas pessoais ou grupais. $\mathrm{O}$ mal está em emprestar um caráter de verdade científica a esses testes e a essa busca. As ciências naturais não vão nunca resolver os nossos problemas com o racismo, com a discriminação racial e sexual, com os preconceitos, com a opressão e a exploração. Nós criamos estes problemas na interação social, impregnamos nossas relações com este simbolismo, fazemos cultura constrangidos por ele. Temos obrigação de romper esses males a partir da nossa reflexão sobre o mundo social e sua história.

Guerreiro Ramos não via alternativas à racialização que não fosse o nacionalismo. Sua desconfiança de outros processos de formação racial era tão grande que, se leu Fanon, não o aceitou. Quanto à racialização dos nordestinos em São Paulo, este não é um processo bem-sucedido. Os nordestinos têm identidades regionais muito bem definidas - baianos, pernambucanos, paraibanos etc. - e não se deixam facilmente racializar como nordestinos. Podem até formar um grupo étnico, mas nunca uma raça. Isso nos ensina mais sobre a racialização: ela pode ou não ser bem-sucedida. Eu diria que a falta de outros referentes, que não a raça atribuída pelos outros, ou seja, a perda de identidades étnicas, nacionais, ou mesmo religiosas, fragiliza os grupos racializados. Ao mesmo tempo, o esforço da racialização ganha uma força enorme quando amparada na ciência. Imagine, por exemplo, que a ciência genética que se faz hoje no Brasil "demonstre" que, ao contrário dos paulistas e sulistas, os nordestinos 
são miscigenados, ou seja, apresentam características genéticas diferentes do resto da população paulista. Pois bem, se essa crença se estabelecer como verdade através das práticas científicas e de sua aplicação no dia a dia - na medicina e na ciência forense, por exemplo -, estaremos nós, nordestinos, em muito maus lençóis para nos defendermos da racialização.

Por fim, encerremos com a interseccionalidade entre classe, gênero, nação e raça. Espero ter demonstrado que não se pode entender a formação nacional brasileira sem ter plena consciência da centralidade para nós das classes sociais como um ideal de justiça social e de comportamento. Até mesmo, ou principalmente, quando discriminamos, fazemos isso imersos nesse ideário que nos faz sentir inocentes de qualquer racismo ou sexismo, pois encobrimos valorativamente todos os comportamentos na métrica de classe. Daí o sucesso e a persistência que gozou a narrativa da democracia racial. Se hoje ela cedeu lugar para a formação racial negra, foi porque a formação de classe também ganhou contornos de antagonismo no plano político e a sexualidade fugiu ao completo controle do patriarcado.

\section{Referências Bibliográficas}

Albuguerque, W. R. de. (2009), O jogo da dissimulação: abolição e cidadania negra no Brasil. São Paulo, Companhia das Letras.

Azevedo, Thales de. (1956), “Classes sociais e grupos de prestígio”. Arquivos da Universidade Federal da Babia, Faculdade de Filosofia, Salvador, n. 5. In: (1966), Cultura e situação racial no Brasil. Rio de Janeiro, Civilização Brasileira.

Arendt, Hannah. (1994), Eichmann in Jerusalem: a report on the banality of evil. Nova York, Penguin Books.

Banton, Michael (1977), The idea of race. Londres, Tavistock. . (2012), "The colour line and the colour scale in the twentieth century". Ethnic and Racial Studies, 35 (7): 1109-1131.

BILGE, Sirma. (2013), "Intersectionality undone: saving intersectionality from feminist intersectionality studies”. Du Bois Review, 10 (2): 405-424.

Bourdieu, Pierre. (1987), "What makes a social class? On the theoretical and practical existence of groups”. Berkeley Journal of Sociology, (32): 1-17. . (2007), A distinção: crítica social do julgamento. São Paulo, Edusp.

Carastathis, A. (2014), "The concept of intersectionality in feminist theory". Philosophy Compass, 9 (5): 304-314.

Du Bors, W. E. B. (1903), The souls of black folk. Nova York, Dover.

Durkheim, Émile. (1894), Les règles de la méthode sociologique. Un document produit en version numérique par Jean-Marie Tremblay, dans le cadre de la collection "Les Classiques 
des Sciences Sociales". Disponível em http://www.uqac.uquebec.ca/zone30/Classiques_ des_sciences_sociales/index.htl, consultado em 4/2/2016.

Duster, Troy. (2003), Backdoor to eugenics. Londres, Routledge.

(2006), "Comparative perspectives and competing explanations: taking on the newly configured reductionist challenge to sociology”. American_Sociological Review, 71 (1): 1-15.

Elias, Norbert. (1998), "Group charisma and group disgrace”. In: Goudsblom, Johan \& Mennell, Stephen. (1998), The Norbert Elias reader. Oxford, Blackwell.

. (1981), Qu'est-ce que la sociologie?. Paris, Pandora.

Elias, Nobert \& Scotson, John. (1965), The established and the outsiders. Londres, Frank Cass \& Co. Ltd.

Guimarães, A. S. A. (2012a), "Sociology and racial inequality: chalenges and approaches in Brazil”. In: Dixon, Kwame \& Burdick, John (orgs.). Comparative perspectives on AfroLatin America. Gainsville, University Press of Florida, vol. 1, pp. 305-324.

(2012b), "The Brazilian system of racial classification". Ethnic and Racial Studies, 35 (7): 1157-1162.

Grusky, D. \& Galescu, G. (2007), “Foundations of neo-durkheimian class analysis”. In: Wright, E. Approaches to class analysis. Cambridge, Cambridge University Press, pp. 51-81.

Hancock, A.-M. (2007), “When multiplication doesn't equal quick addition: examining intersectionality as a research paradigm”. Perspectives on Politics, 5 (1): 63-79.

HARris, Marvin \& KotaK, Conrad. (1963), “The structural significance of Brazilian categories". Sociologia, 3 (xxv): 203-208.

LYKKE, N. (2011), "Intersectional analysis: black box or useful critical feminist thinking technology”. In: Lutz, H.; VIVAR, M. T. H. \& SupIK, L. Framing intersectionality: debates on a multi-faceted concept in gender studies. Farnham, Ashgate, pp. 207-220.

Kent, M. et al. (2015), "Building the genomic nation 'Homo Brasilis' and the 'Genoma Mexicano' in comparative cultural perspective”. Social Studies of Sciences, 45 (6): 839-861.

Kergoat, D. (2010), "Dinâmica e consubstancialidade das relações sociais". Novos Estudos Cebrap, (86): 93-103.

Martius, Karl Friedrich von \& Rodrigues, José Honório. (1956), “Como se deve escrever a História do Brasil”. Revista de Historia de América, 42: 433-458.

Nash, J. (2008), "Re-thinking intersectionality”. Feminist Review, 89: 1-15.

OMi, M. \& Winant, H. (1994), “Racial formation”. In: Racial formation in the United States: from the 1960s to the 1990s. Nova York, Routledge.

Ortiz, Fernando. (1940), Contrapunteo cubano del tabaco y del azúcar. Habana, J. Montero. Przeworski, Adam. (1977), "Proletariat into a class: the process of class formation from Karl Kautsky's The class struggle to recent controversies”. Politics \& Society, 4 (7): 343-401. Ramos, A. G. (1957), Introdução crítica à sociologia brasileira. Rio de Janeiro, Editorial Andes. 
Rodrigues, Nelson. ([1958] 1993), “O complexo de vira-latas”. In: Castro, Ruy (org.). $A ̀$ sombra das chuteiras imortais: crônicas de futebol. São Paulo, Companhia das Letras, pp. 51-52 [publicado originalmente em Manchete Esportiva, 31 maio 1958].

Silvério, Válter. (2013), "Multiculturalismo e metamorfose na racialização: notas preliminares sobre a experiência contemporânea brasileira”. In: BonELLI, Maria da Gloria \& LANDA, Martha Diaz Villegas de (orgs.). Sociologia e mudança social no Brasil e na Argentina. São Carlos, Compacta, pp. 33-60.

Telles, Edward \& Ethnicity and Race in Latin America (perla). (2014), Pigmentocracies: ethnicity, race and color in Latin America. Chapel Hill, University of North Carolina Press.

Tourraine, Alain. (1961), “Ouvriers et syndicats d'Amérique Latine”. Sociologie du Travail, número especial, 3 (4).

WADE, Peter et al. (2015), "Genomic research, publics and experts in Latin America: nation, race and body". Social Studies of Science, 45 (6): 775-796. Disponível em http://sss.sagepub. com/content/45/6, consultado em 15/1/2016.

WAGLEY, Charles. (1952), "Comment les classes ont remplacé les castes dans le Brésil septentrional". In: WAgLeY, Charles (ed.). Races et classes dans le Brésil rural. Paris, Unesco.

Weber, Max. (2006), A 'objetividade' do conhecimento nas ciências sociais. São Paulo, Ática.

Weinstein, B. (2015), The color of modernity: São Paulo and the making of race and nation in Brazil. Durham/Londres, Duke University Press.

Wimmer, A. (2008), "The making and unmaking of ethnic boundaries". American Journal of Sociology, 113 (4): 970-1022. . (2013), Ethnic boundary making: institutions, power, networks. Nova York, Oxford University Press.

\section{Resumo}

Formações nacionais de classe e raça

Neste texto, proponho a releitura de dois conceitos-chave nos estudos históricos sobre racismo e movimentos sociais negros nas Américas - racialização e formação racial -, examinando-os à luz das teorias das classes sociais e da formação de grupos sociais em geral. Meu ponto de partida é que esses conceitos não podem ser operacionalizados na análise de processos históricos senão em concomitância com análises concretas de formações nacionais e de classes. Tomo o Brasil moderno e contemporâneo para sustentar empiricamente os processos históricos que podem fundamentar a minha proposta conceitual.

Palavras-chave: Classes sociais; Radicalização; Formação racial; Formação nacional. 


\section{Abstract}

National formations of class and race

In this paper, I propose and use a new understanding of two key concepts in historical studies on racism and black social movements in the Americas - racialization and racial formation - by examining them in the light of the theories of social classes and the formation of social groups in general. My starting point is that these concepts can not be operated on the analysis of historical processes but concomitantly with concrete analyzes of national and classes formations. I take the modern and contemporary Brazil to empirically exam the historical processes that can empirically substantiate my conceptual proposal.

Keywords: Social classes; Racialization; Racial formation; National formation.

Texto enviado em 15/1/2016 e aprovado em 2/2/2016. DoI: 10.11606/0103-2070.ts.2016.10 9752.

Antonio Sérgio Alfredo Guimarães possui graduação (1972) e mestrado (1982) em ciências sociais pela Universidade Federal da Bahia e doutorado em sociologia pela University of Wisconsin - Madison (1988). Atualmente é professor titular da Universidade de São Paulo. E-mail: antonio.sergio@me.com. 